\title{
Correction to: Social media networks and pedagogy at the University of Jordan
}

\author{
Huda Karajeh ${ }^{1}$ - Mahmoud Maqableh ${ }^{2}$. \\ Lama Rajab ${ }^{1}$ - Hiba Mohammad ${ }^{1}$. \\ Tahani Khatib $^{1}$ - Nabeel Al-Qirim ${ }^{3}$ (D) Ali Tarhini ${ }^{4}$
}

Published online: 9 August 2018

(C) Springer Science+Business Media, LLC, part of Springer Nature 2018

\section{Correction to: Educ Inf Technol \\ https://doi.org/10.1007/s10639-018-9704-8}

The authors would like to note that one of the co-author's names was displayed incorrectly. Not Nabil Al-Qirim, but Nabeel Al-Qirim co-authored this article as shown above.

The original article has been corrected.

The online version of the original article can be found at https://doi.org/10.1007/s10639-018-9704-8

Nabeel Al-Qirim

nalqirim@uaeu.ac.ae

Huda Karajeh

h.karajeh@ju.edu.jo

Mahmoud Maqableh

maqableh@ju.edu.jo

Lama Rajab

lama.rajab@ju.edu.jo

Hiba Mohammad

h.khadrawi@ju.edu.jo

Tahani Khatib

tahani.khatib@ju.edu.jo

Ali Tarhini

ali.tarhini@hotmail.co.uk 
1 Department of Computer Information Systems, King Abdullah II School for Information Technology, University of Jordan, Amman 11942, Jordan

2 Department of Management Information Systems, Faculty of Business, The University of Jordan, Amman 11942, Jordan

3 College of Information Technology, United Arab Emirates University, Al-Ain, United Arab Emirates

4 Department of Information Systems, Sultan Qaboos University, Muscat, Oman

Springer 